\title{
Relationship between the mothers' nutritional status with that of a child population from São Tomé Principe, "Africa"
}

\author{
Diana e Silva 1 \\ Ana Valente 2 \\ Andreia Borges 3 \\ Cláudia Dias 4 \\ Feliciana Almeida 5 \\ José Luís Cruz 6 \\ Edgar Neves 7 \\ Caldas Afonso 8 \\ António Guerra 9 \\ 1 Unidade de Nutrição/Hospital Pediátrico Integrado/Centro Hospitalar São João. Faculdade Ciências Nutrição e Alimentação. Universidade Porto \\ (FCNAUP). Alameda Hernâni Monteiro, 4200-319. Porto, Portugal. E-mail: diana.mv.silva@gmail.com \\ 2,3 Faculdade de Ciências da Nutrição e Alimentação. Universidade do Porto. Porto, Portugal. \\ 4 Serviço de Bioestatística e Informática Médica. Faculdade Medicina Universidade Porto. Porto, Portugal \\ 5,6 Hospital Dr Ayres de Menezes. São Tomé e Príncipe \\ 7 Instituto Marques Valle Flor, São Tome Príncipe \\ 8,9 Hospital Pediátrico Integrado/Centro Hospitalar São João. Faculdade Medicina. Universidade Porto. Porto, Portugal.
}

\begin{abstract}
Objectives: analyse the relation between the nutritional status of children with 0 to 60 months in São Tome and Principe (STP) and their mothers.

Methods: characterization of the nutritional status of 1,169 children for the weight 1 length ratio $(W / L)(\leq 24$ months) and Body Mass Index (BMI) for age (>24months) and their mothers. The Chi Square or Fisher tests were used for the study on the relation between the nutritional status of the mother and children, as appropriate.

Results: fifty-five percent (55\%) of the children are female (median $=21$ months). There was a high percentage of global acute malnutrition in the children aged $0 \leq 24$ months (30.2\%) and $24 \leq 60$ months (22\%) as well as global chronic malnutrition (32\% and $41.1 \%$ respectively). We observed a high percentage of overweight lobese mothers (31.6\%), with $16.5 \%$ of them being of a low height. We observed a significantly higher percentage of children with global acute malnutrition $47.5 \%$ ) when compared with that which was reported for children of normal mothers $(27.9 \%)$ or overweight lobese $(22 \%)(p<0,001)$ mothers.

Conclusions: It was observed a high prevalence of acute and chronic global malnutrition in the children studied and a high prevalence of overweight lobese mothers. We observed a statistically significant association between maternal and acute global malnutrition of the children.
\end{abstract}

Key words Maternal nutrition, Child nutrition, Malnutrition 


\section{Introduction}

Although there is currently a decline in the prevalence of global malnutrition in the under-five population, 120 million children are still underweight in developing countries, 200 million are stunted (chronic malnutrition) and approximately 30 million are wasted (acute malnutrition), confirming that different forms of malnutrition remain a seriousworldwide public health problem.1,2

In São Tomé and Príncipe (STP), an economically disadvantaged African country, 1 in 15 children dies before the age of 5 , and malnutrition may account for more than $50 \%$ of these deaths. ${ }^{3,4} \mathrm{On}$ a global scale, malnutrition is associated with one third of the deaths in children under the age of 5.1

The paradoxical phenomenon of the coexistence in the same family of chronically undernourished children and their overweight/obese mothers has been observed in several studies, suggesting an emerging problem in developing countries. 5

Nutritional status has several implications for the health and the welfare of populations, particularly in periods of rapid growth and development, such as pregnancy and early childhood. 6 The negative consequences of malnutrition range from the impairment of physical and psychosocial development as wellas irreversible cognitive impairment, to the reduction of productive and learning capacity, and even the risk of deaths associated with chronic diseases. ${ }^{7}$

The causes and consequences of malnutrition in children under the age of five indicate pregnancy and the period preceding it, as well as childhood, right from birth, as a window of opportunity in which an adequate nutritional intervention can provide adequate growth and development.1,8 Thus, the mother represents an important link between the child and the environment, since an intimate motherchild relationship is established from gestation and throughout childhood, until the biological and social independence of the child. 9,10

Some studies have found that chronic malnutrition during childhood and obesity in adulthood may have common determinants, both biological and socio-environmental. ${ }^{10,11} \mathrm{~A}$ study conducted by the University of São Paulo / Brazil noted that most undernourished children hadoverweight/obese mothers. ${ }^{11}$ Other authors observed that lowheight of mothers was associated with child malnutrition, both in mothers with weight deficits and those with overweight / obesity. ${ }^{5}$ On the other hand, the emerging parental paradox observed in developing countries where children with chronic malnutrition and obese mothers cohabit side by side is a huge challenge in children under the age of five. $10,12,13$ The relationship between the nutritional status of the motherchild binomial is poorly studied, and thus it is of interest to better understand this relationship. Therefore, it is important to analyze the nutritional status among family members throughout the different periods of life. 10,12 It is central to emphasize the nutritional assessment of the child considering their family context and their interaction with the environment.

\section{Methods}

It is a sectorial study, with a no probabilistic sample (for convenience), that assessed the children between the ages of 0 to 6 attended at the health units in the six districts of São Tomé and Principe (Affric), between February and May, 2011. First, 1.285 children were selected based on the records of children enrolled in the national vaccination program in the year 2010. Among these, 118 children were excluded because they could not be measured or weighed. Children with congenital malformation delays in the psychomotor development, and chronic pathologies with repercussion in the nutritional statewere also excluded.

The nutritional assessment protocol included the weight and length/height measurement according to the international methodology and technique recommended. 14 The characterization of the nutritional status was done by the weight / length ratio $(\mathrm{W} / \mathrm{L})(\leq 24$ months) and Body Mass Index (BMI) of Quetelet $\left[\mathrm{BMI}=\right.$ weight $(\mathrm{kg}) /$ height $\left.\left.(\mathrm{cm})^{2}\right)\right]$ for the ages (24-60 months) obtained through the $z$-scores in accordance with the WHO Anthro (version 3.1, April 2012) software, according to the child growth charts of the World Health Organization (WHO). 15 The nutritional state was classified according to the predefined cutoffs. 16 The mother's nutritional assessments were determined by the BMI using the WHO recommendation. ${ }^{17}$ Low maternal height was considered to be the height below one meter and fifty five centimeters $(<1,55 \mathrm{~m}) .5$

A pilot study was previously carried out to test the protocol and the trainingteam who collected the data.

The study was approved by the Ethics Committee of Hospital Dr. Ayres Meneses and Centro Hospitalar São João - Porto - Portugal.

Collected data was introduced in the MedQuest online tool. Categorical variables were described as absolute frequencies (n) and relative frequencies (\%). Median and percentiles or mean and standard deviation were used for continuous variables, taking 
into account the normality of the variables.

A chi-square test and Fisher's exact test were used, as appropriate, when testing a hypothesis about categorical variables.

The significance lever used was 0.05. Statistical analysis was performed using the Statistical Package software for Social Sciences v. 20.0. The results were presented by total sample and each age group: $0 \leq 24 ;>24 \leq 60$ months and according to the mother's height $(<1,55 \mathrm{~m} \mathrm{e} \geq 1,55 \mathrm{~m})$.

\section{Results}

Of the 1.169 children studied, the majority $(54.7 \%)$ belonged to the female sex. The mean age was $25,2 \pm 18$ months (minimum $=0$; maximum $=60$ ) with a median age of 21 months. The majority of children (56.5\%) was between 0 and 24 months. A high percentage of acute global children malnutrition at this age (31.8\%) and between 24 and 60 months $(10.9 \%)$ was observed. Regarding the length/ height deficit for the age, $6.9 \%$ of the children presented this condition. $32.7 \%$ and $40.8 \%$ of the children with chronic global malnutrition, respectively, at the ages of $<24$ months and $\geq 24$ months and stunting rate of $11.6 \%$ in the total sample (Table 1).
Although the majority of mothers had a normal BMI, $31.9 \%$ of them were overweight/ obese. Of the total sample $(\mathrm{n}=1.169), 16.4 \%$ had a low height $(<1,55 \mathrm{~m})$ and $33.3 \%$ of them were overweight/ obese (Table 2).

The percentages of acute and chronic global malnutrition in children according to maternal nutrition status are presented in Figure 1. Children with obese mothers were more likely to present chronic global malnutrition than global chronic malnutrition. On the contrary, the proportion of children with acute malnutrition was higher than those with chronic malnutrition among malnourished mothers. Both in the group of mothers with height below $1.55 \mathrm{~m}(\mathrm{n}=192)$, as well as in the ones with the height above $1.55 \mathrm{~m}(\mathrm{n}=977)$, there are significantly higher frequencies of global acute malnutrition in children of malnourished mothers, compared to eutrophic or obese mothers, respectively $47 . \%, 27.9 \%$ and $22.0 \%$ when the total sample is considered (Table 3).

There are no significant associations between the nutritional status of mothers and the percentage of children with global chronic malnutrition, taking into account maternal height $(<1.55 \mathrm{~m}$ and $\geq 1.55 \mathrm{~m})$ (Table 4).

Table 1

Nutritional status characterization of children 0 to 60 months. São Tomé e Príncipe (Africa), 2011.

\begin{tabular}{|c|c|c|c|}
\hline \multicolumn{4}{|c|}{ Global Acute Malnutrition } \\
\hline & $\begin{array}{c}\leq 24 \text { months } \\
\quad(n=661)\end{array}$ & $\begin{array}{c}>24 \text { months } \\
(n=508)\end{array}$ & $\begin{array}{c}\text { Total } \\
(n=1169)\end{array}$ \\
\hline \multicolumn{4}{|c|}{ Nutritional Status } \\
\hline \multicolumn{4}{|c|}{$\mathrm{W} / \mathrm{L}$ or $\mathrm{BMI}, \%$} \\
\hline$<-3$ & 2.3 & 2.8 & 2.5 \\
\hline$\geq-3$ e $<-2$ & 6.2 & 2.2 & 4.4 \\
\hline$\geq-2$ e $<-1$ & 23.3 & 5.9 & 20.1 \\
\hline$\geq-1$ e $<2$ & 66.7 & 66.6 & 71.0 \\
\hline$\geq 2$ e $<3$ & 1.2 & 1.4 & 1.3 \\
\hline \multirow[t]{3}{*}{$\geq 3$} & 0.3 & 1.2 & 0.7 \\
\hline & \multicolumn{3}{|c|}{ Global Chronic Malnutrition } \\
\hline & $\begin{array}{c}\leq 24 \text { months } \\
(n=661)\end{array}$ & $\begin{array}{c}>24 \text { months } \\
(n=508)\end{array}$ & $\begin{array}{c}\text { Total } \\
(n=1169)\end{array}$ \\
\hline \multicolumn{4}{|c|}{ Nutritional Status } \\
\hline \multicolumn{4}{|l|}{$H / A, \%$} \\
\hline$<-3$ & 2.1 & 2.6 & 2.3 \\
\hline$\geq-3$ e $<-2$ & 9.7 & 8.9 & 9.3 \\
\hline$\geq-2$ e $<-1$ & 20.9 & 29.3 & 24.6 \\
\hline$\geq-1$ e $<2$ & 64.8 & 58.1 & 61.8 \\
\hline$\geq 2$ e $<3$ & 1.7 & 1.0 & 1.4 \\
\hline$\geq 3$ & 1.1 & 0.2 & 0.7 \\
\hline
\end{tabular}

$\mathrm{W} / \mathrm{L}=$ weight for length; $\mathrm{BMI}=$ Body Mass Index 
Nutritional status characterization of mothers, by BMI and height. São Tomé e Príncipe (Africa), 2011.

\begin{tabular}{|c|c|c|}
\hline & \multicolumn{2}{|c|}{ Mothers } \\
\hline Age $(\overline{\mathrm{X} \pm} \mathrm{SD})$ & \multicolumn{2}{|c|}{$28 \pm 7$} \\
\hline Nutritional Status (BMI) & $\mathrm{n}$ & $\%$ \\
\hline$<18.5$ & 59 & 5.0 \\
\hline$[18.5-25[$ & 738 & 63.1 \\
\hline$[25-30[$ & 257 & 22.0 \\
\hline$[30-35[$ & 79 & 6.8 \\
\hline$[35-40[$ & 29 & 2.5 \\
\hline$\geq 40$ & 4 & 0.6 \\
\hline \multicolumn{3}{|l|}{ Height } \\
\hline$<1.55 \mathrm{~m}$ & 192 & 16.4 \\
\hline \multicolumn{3}{|l|}{ Nutritional Status (BMI) } \\
\hline$<18.5$ & 7 & 3.6 \\
\hline$[18.5-25[$ & 121 & 63.0 \\
\hline$[25-30[$ & 48 & 25.0 \\
\hline$[30-35[$ & 10 & 5.2 \\
\hline$[35-40[$ & 5 & 2.6 \\
\hline$\geq 40$ & 1 & 0.5 \\
\hline$\geq 1.55 \mathrm{~cm}$ & 977 & 83.6 \\
\hline \multicolumn{3}{|l|}{ Nutritional Status (BMI) } \\
\hline$<18.5$ & 52 & 5.3 \\
\hline$[18.5-25[$ & 617 & 63.2 \\
\hline$[25-30[$ & 209 & 21.4 \\
\hline$[30-35[$ & 69 & 7.1 \\
\hline$[35-40[$ & 24 & 2.5 \\
\hline$\geq 40$ & 6 & 0.6 \\
\hline
\end{tabular}

BMI = Body Mass Index. 
Association between mother's nutritional status (BMI) and height, according to children's acute malnutrition(W/L and BMI). São Tomé e Principe (Africa), 2011.

\begin{tabular}{|c|c|c|c|c|c|c|c|}
\hline \multirow{4}{*}{$\begin{array}{l}\text { W/L }(\leq 24 m) \\
\text { BMI }(>24 m)\end{array}$} & \multicolumn{7}{|c|}{ Mother'sheight $<1.55 \mathrm{~m}(\mathrm{n}=192)$} \\
\hline & \multicolumn{6}{|c|}{ Mother's BMI } & \\
\hline & \multirow{2}{*}{\multicolumn{2}{|c|}{$\begin{array}{l}<18.5 \\
(n=7)\end{array}$}} & \multirow{2}{*}{\multicolumn{2}{|c|}{$\begin{array}{c}15.5-24.99 \\
(n=121)\end{array}$}} & \multirow{2}{*}{\multicolumn{2}{|c|}{$\begin{array}{l}>=25 \\
(n=64)\end{array}$}} & \multirow[t]{3}{*}{$p^{*}$} \\
\hline & & & & & & & \\
\hline & $\mathrm{n}$ & $\%$ & $\mathrm{n}$ & $\%$ & $\mathrm{n}$ & $\%$ & \\
\hline \multicolumn{8}{|l|}{ malnutrition status } \\
\hline$\geq-1$ & 2 & 28.6 & 79 & 65.3 & 50 & 78.1 & \\
\hline$<-1$ & 5 & 71.4 & 42 & 34.7 & 14 & 21,9 & \\
\hline Children's & & & & & & & 0.043 \\
\hline \multicolumn{8}{|l|}{ malnutrition status } \\
\hline$\geq-2$ & 5 & 71.4 & 113 & 93.4 & 62 & 96.9 & \\
\hline \multirow[t]{5}{*}{$<-2$} & 2 & 28.6 & 8 & 6.6 & 2 & 3,1 & \\
\hline & \multicolumn{7}{|c|}{ Mother's height $\geq 1.55 \mathrm{~m}(\mathrm{n}=977)$} \\
\hline & \multicolumn{6}{|c|}{ Mother's BMI } & \\
\hline & \multicolumn{2}{|c|}{$\begin{array}{l}<18.5 \\
(n=52)\end{array}$} & \multicolumn{2}{|c|}{$\begin{array}{c}15.5-24.99 \\
(n=617)\end{array}$} & \multicolumn{2}{|c|}{$\begin{array}{c}>=25 \\
(n=308)\end{array}$} & $p^{*}$ \\
\hline & $\mathrm{n}$ & $\%$ & $n$ & $\%$ & $\mathrm{n}$ & $\%$ & \\
\hline $\begin{array}{l}\text { Children's } \\
\text { malnutrition status }\end{array}$ & \multicolumn{6}{|c|}{ malnutrition status } & \\
\hline$\geq-1$ & 29 & 55.8 & 453 & 93.5 & 240 & 77.9 & \\
\hline$<-1$ & 23 & 44.2 & 164 & 26.6 & 68 & 22.1 & \\
\hline Children's & & & & & & & 0.375 \\
\hline \multicolumn{8}{|l|}{ malnutrition status } \\
\hline$\geq-2$ & 46 & 88.5 & 577 & 93.5 & 285 & 92.5 & \\
\hline \multirow[t]{5}{*}{$<-2$} & 6 & 11.5 & 40 & 6.5 & 23 & 7.5 & \\
\hline & \multicolumn{6}{|c|}{ Global $(n=1169)$} & \\
\hline & \multicolumn{6}{|c|}{ Mother's BMI } & \\
\hline & \multicolumn{2}{|c|}{$\begin{array}{l}<18.5 \\
(n=59)\end{array}$} & \multicolumn{2}{|c|}{$\begin{array}{c}15.5-24.99 \\
(n=738)\end{array}$} & \multicolumn{2}{|c|}{$\begin{array}{c}>=25 \\
(n=372)\end{array}$} & $p^{*}$ \\
\hline & $\mathrm{n}$ & $\%$ & $\mathrm{n}$ & $\%$ & $\mathrm{n}$ & $\%$ & \\
\hline \multicolumn{7}{|l|}{ malnutrition status } & $<0.001$ \\
\hline$\geq-1$ & 31 & 52.5 & 532 & 72.1 & 290 & 78.0 & \\
\hline$<-1$ & 29 & 47.5 & 206 & 27.9 & 82 & 22.0 & 0.119 \\
\hline \multirow{2}{*}{\multicolumn{8}{|c|}{$\begin{array}{l}\text { Children's } \\
\text { malnutrition status }\end{array}$}} \\
\hline & & & & & & & \\
\hline$\geq-2$ & 51 & 52.5 & 690 & 93.5 & 347 & 93.3 & \\
\hline$<-2$ & 8 & 13.6 & 48 & 6.5 & 25 & 6.7 & \\
\hline
\end{tabular}

*Pearson's chi-squared test:W/L= Weight for Length; BMI = Body Mass Index. 
Association between mother's nutritional status (BMI) and height, according to children's chronic malnutrition(L/A and H/A). São Tomé e Principe (Africa), 2011.

\begin{tabular}{|c|c|c|c|c|c|c|c|}
\hline \multirow{4}{*}{$\begin{array}{l}\mathrm{L} / \mathrm{A}(\leq 24 \mathrm{~m}) \\
\mathrm{H} / \mathrm{A}(>24 \mathrm{~m})\end{array}$} & \multicolumn{6}{|c|}{ Mother'sheight $<1.55 \mathrm{~m}(\mathrm{n}=192)$} & \multirow{4}{*}{$p^{*}$} \\
\hline & \multicolumn{6}{|c|}{ Mother's BMI } & \\
\hline & \multirow{2}{*}{\multicolumn{2}{|c|}{$\begin{array}{l}<18.5 \\
(n=7)\end{array}$}} & \multirow{2}{*}{\multicolumn{2}{|c|}{$\begin{array}{c}15.5-24.99 \\
(n=121)\end{array}$}} & \multirow{2}{*}{\multicolumn{2}{|c|}{$\begin{array}{l}>=25 \\
(n=64)\end{array}$}} & \\
\hline & & & & & & & \\
\hline & $\mathrm{n}$ & $\%$ & $\mathrm{n}$ & $\%$ & $n$ & $\%$ & \\
\hline Children's & & & & & & & -0.282 \\
\hline \multicolumn{8}{|l|}{ malnutrition status } \\
\hline$\geq-1$ & 2 & 28.6 & 70 & 57.9 & 33 & 51.6 & \\
\hline$<-1$ & 5 & 71.4 & 51 & 42.1 & 31 & 48.4 & \\
\hline Children's & & & & & & & 0.226 \\
\hline \multicolumn{8}{|l|}{ malnutrition status } \\
\hline$\geq-2$ & 4 & 57.1 & 100 & 82.6 & 50 & 78.1 & \\
\hline \multirow[t]{6}{*}{$<-2$} & 3 & 42.9 & 21 & 17.4 & 14 & 21.9 & \\
\hline & \multicolumn{6}{|c|}{ Mother's height $\geq 1.55 \mathrm{~m}(\mathrm{n}=977)$} & \\
\hline & \multicolumn{6}{|c|}{ Mother's BMI } & \\
\hline & \multirow{2}{*}{\multicolumn{2}{|c|}{$\begin{array}{l}<18.5 \\
(n=52)\end{array}$}} & \multirow{2}{*}{\multicolumn{2}{|c|}{$\begin{array}{c}15.5-24.99 \\
(n=619)\end{array}$}} & \multirow{2}{*}{\multicolumn{2}{|c|}{$\begin{array}{c}>=25 \\
(n=308)\end{array}$}} & $p^{*}$ \\
\hline & & & & & & & \\
\hline & $\mathrm{n}$ & $\%$ & $n$ & $\%$ & $n$ & $\%$ & \\
\hline Children's & & & & & & & 0.312 \\
\hline \multicolumn{8}{|l|}{ malnutrition status } \\
\hline$\geq-1$ & 36 & 69.2 & 394 & 63.9 & 211 & 68.5 & \\
\hline$<-1$ & 16 & 30.8 & 23 & 36.1 & 97 & 31.5 & \\
\hline Children's & & & & & & & 0.503 \\
\hline \multicolumn{8}{|l|}{ malnutrition status } \\
\hline$\geq-2$ & 46 & 88.5 & 553 & 89.3 & 282 & 91.6 & \\
\hline \multirow[t]{6}{*}{$<-2$} & 6 & 11.5 & 66 & 10.7 & 26 & 8.4 & \\
\hline & \multicolumn{6}{|c|}{ Global $(n=1169)$} & \\
\hline & \multicolumn{6}{|c|}{ Mother's BMI } & \\
\hline & \multirow{2}{*}{\multicolumn{2}{|c|}{$\begin{array}{l}<18.5 \\
(n=59)\end{array}$}} & \multirow{2}{*}{\multicolumn{2}{|c|}{$\begin{array}{c}15.5-24.99 \\
(n=738)\end{array}$}} & \multirow{2}{*}{\multicolumn{2}{|c|}{$\begin{array}{c}>=25 \\
(n=372)\end{array}$}} & $p^{*}$ \\
\hline & & & & & & & \\
\hline & $\mathrm{n}$ & $\%$ & $n$ & $\%$ & $n$ & $\%$ & \\
\hline Children's & & & & & & & 0.670 \\
\hline \multicolumn{8}{|l|}{ malnutrition status } \\
\hline$\geq-1$ & 38 & 64.4 & 464 & 62.9 & 244 & 65.6 & \\
\hline$<-1$ & 21 & 35.6 & 274 & 37.1 & 128 & 34.4 & \\
\hline Children's & & & & & & & 0.591 \\
\hline \multicolumn{8}{|l|}{ malnutrition status } \\
\hline$\geq-2$ & 50 & 84.7 & 651 & 88.2 & 332 & 89.2 & \\
\hline$<-2$ & 9 & 15.3 & 87 & 11.8 & 40 & 10.8 & \\
\hline
\end{tabular}

*Pearson's chi-squared test: L/A= Length for age; H/A =Height for age; BMI= Body Mass Index 
Children's acute and chronic global malnutrition, by mother's nutritional status.

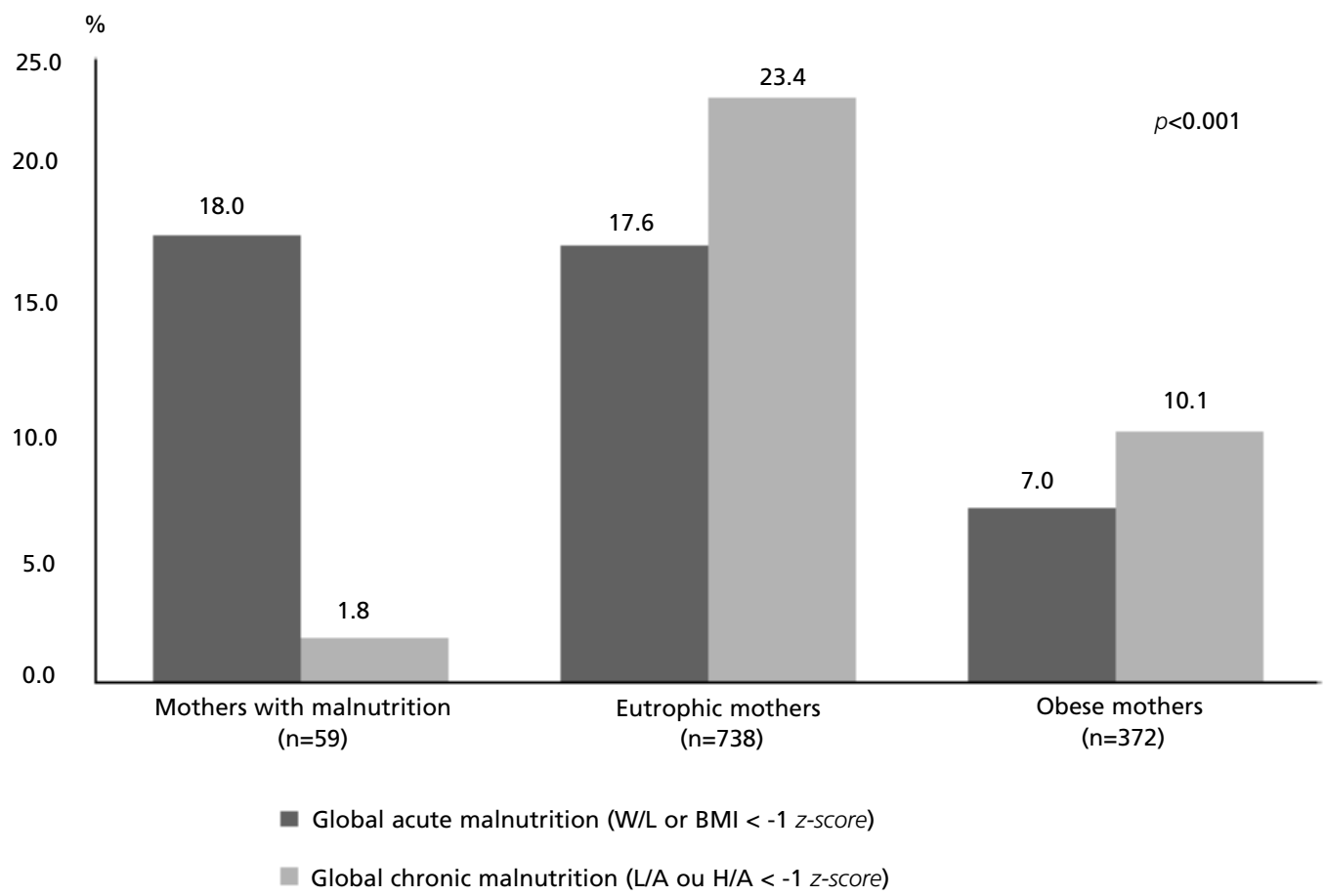

$W / L=$ Weight by length; $L / A=$ Length by age; $H / A=$ Height by age; $B M I=$ Body mass index .

\section{Discussion}

Child malnutrition, as a multifactorial disease resulting from the interrelation of factors such as poverty, infections and reduced energy and protein intake, remains a major public health problem in children under 5 years of age in developing countries. 4,12 In the present study, the prevalence of global acute malnutrition found in both age groups ( $\leq 24$ months: $31.8 \%$,> $24 \leq 60$ months: $10.9 \%$ ) (Table 1) is higher than in other studies, where a higher prevalence of acute malnutrition was also observed in children younger than 24 months. $4,10,12,18$

$11.6 \%$ of the total sample was identified as having moderate / severe chronic malnutrition (length/height for age $<-2$ Zsc). These results were lower than those reported by the UNICEF / WHO in São Tomé, where percentages of malnutrition ranged from 29 to $35 \%$ in this same age group from 1986 to 2008.4 Yet, considering the prevalence of global chronic malnutrition (length/height for age $<-1$ zscore), a higher percentage of malnutritionwas observed in children older than 24 months $(40.8 \%)$ when compared to children under 24 months
(32.7\%). High prevalence of chronic malnutrition is usually associated with insufficiency / inefficiency of public policies as well as appropriate health/nutrition interventions to both mother and child. 1

The early nutritional assessment and orientation of the mother and child helps to identify potential risk situations for malnutrition and prevents the occurrence of adverse consequences arising from the synergy between malnutrition and infection, reducing the prevalence of acute malnutrition and avoiding chronic malnutrition. This action also contributes to the reduction of the risk of future overweight and obesity in adolescence and adulthood, which are associated with a higher risk of developing chronic-degenerative diseases, such as diabetes, hypertension and other non-communicable diseases. ${ }^{18-} 21$ Therefore it is considered that this should be a priority in public health policies, especially in countries with a high prevalence of child malnutrition. 1,3

Several studies have observed that in a similar background to that of São Tomé, children with an adequate nutritional monitoring have significant improvements in their nutritional status and health, 
with a consequent decrease in risks associated with malnutrition. ${ }^{18,21}$ Thus, guidance and monitoring of maternal and child nutritional status constitutes an investment, with proven benefits to the present and future generations. 1,10,22

The high prevalence of maternal overweight obesity (Table 2) has been reported as a consequence of chronic malnutrition during the mother's childhood.5,10 Populations exposed to chronic food restriction during childhood and consequent malnutrition, are frequently shorter, which is usually associated with a high predisposition to the development of obesity and metabolic complications in adolescence and adulthood.5,10 This condition may be related to the decrease in the energy expenditure of these children.23 A study conducted by the University of São Paulo, Brazil, also observed that the majority ofundernourished children had overweight / obese mothers. 11 Thus, it is fundamental to recognize that both infant / child malnutrition and maternal obesity may have a common etiology, both of which are significantly associated with poverty and adverse conditions of their environment. 4,24

The results observed in the present study identified $33.3 \%$ of overweight/obesity in mothers with short stature $(<1.55 \mathrm{~m})$ and $16.4 \%$ in mothers with a height of $\geq 1.55 \mathrm{~m}$. It was also observed that among the overweight/obese mothers, $22.0 \%$ of children had global acute malnutrition (weight for height or BMI <-1 Z-score) and 34.4\% had global chronic malnutrition (length/height for age $<-1$ Z-score). Maternal obesity was more associated with global chronic malnutrition in children (10.1\%) (length/height for age). These results corroborate the findings of other recent studies that reported the association of chronic malnutrition in children with maternal overweight / obesity. 25 It should be emphasized that the parents' height, and in this particular case that of the mother, should not be considered only as dependent on genetic factors, but also as a result of environmental factors.

There has been an increase in the prevalence of obesity even in developing countries, with the occurrence of malnutrition and overweight / obesity in the same family. ${ }^{26}$ This situation is particularly reported

\section{References}

1. UNICEF. Tracking progress on child and maternal nutrition: A survival and development priority. New York; 2009. Disponível em: http://www.unicef.org/publications files/Tracking_Progress_on_Child_and_Maternal_Nutritio n_EN_110309.pdf among children with chronic malnutrition (stunting) and overweight / obese mothers, both in developing countries or in nutritional transition, associated with the economic development, and being more prevalent in Latin American countries than in Africa. 27,28 In the present study, a significant association between maternal and child nutrition status was observed, with a higher prevalence of global acute malnutrition in the children of malnourished mothers, despite the maternal height. A significant association between maternal malnutrition and the prevalence of wasting (weight for height or BMI $<-2$ $Z$-score) was only seen in mothers with a height less than $1.55 \mathrm{~m}$. The multiplicity of indicators of malnutrition identified in this study and in other population studies leads us to relate malnutrition only to the lack of economic and / or food resources in a reductionist view of the problem, 10 making it necessary to have a thorough knowledge of the socioeconomic and cultural context, along with an understanding of the complexity of their interactions, with the purpose of establishing timely strategies to solve the problem of malnutrition during childhood. 3

The inherent challenge in conducting epidemiological studies in low-resource countries allows for an awareness of the possible bias of anthropometric parameters, which may be due to intrinsic errors in measurements by different professionals and also to the equipment used with little resolution capacity and deficient gauging, which may have influenced the results found in this study.

In summary, there was a high prevalence of global acute and chronic malnutrition, along with a high prevalence of overweight / maternal obesity in São Tomé and Príncipe. A significant association was identified between maternal malnutrition and global acute malnutrition in children, with maternal obesity being more associated with chronic malnutrition in children. A greater and more effective nutritional intervention, particularly focusing on women in the reproductive age, pregnant women, and in the child's first years of life would be desirable.

2. Glover-Amengor M, Agbemafle I, Hagan LL, Mboom FP, Gamor G, Larbi A, et al. Nutritional status of children 0-59 months in selected intervention communities in northern Ghana from the africa RISING project in 2012. Arch Public Health. 2016; 74: 12. 
3. UNICEF. The State of the World's Children 2008: Women and Children - Child Survival. New York; 2008. Disponível em: http://www.unicef.org/sowc08/docs/sowc08.pdf.

4. WHO Global Nutrition Report 2014. Sao Tome and Principe. Nutrition Country Profile:http://ebrary.ifpri.org/ utils/getfile/collection/p15738coll2/id/128655/filename/128866.pdf

5. Silveira K, Alves J, Ferreira H, Sawaya A, Florêncio T. Association between malnutrition in children living in favelas, maternal nutritional status, and envirnonmental factors. J Pediatr. 2010; 86 (3): 215-20.

6. Naja F, Nasreddine L, Al Thani AA, Yunis K, Clinton M, Nassar A, et al. Study protocol: Mother and Infan Nutritional Assessment (MINA) cohort study in Qatar and Lebanon. BMC Pregnancy Childbirth. 2016; 16: 98.

7. Huffman SL, Schofield D. Consequences of malnutrition in early life and strategies to improve maternal and child diets through targeted fortified products [Introductory]. Matern Child Nutr. 2011; 7 (Suppl 3): 1-4.

8. Vitolo MR, Gama CM, Bortolini GA, Campagnolo PD, Drachler Mde L. Some risk factors associated with overweight, stunting and wasting among children under 5 years old. J Pediatr. 2008; 84 (3): 251-7.

9. Monteiro CA. A dimensão da pobreza, da desnutrição e da fome no Brasil. Estud Av. 2003; 17 (48): 7-20.

10. Martins IS, Marinho SP, de Oliveira DC, de Araujo EA. [Poverty, malnutrition and obesity: interrelationships among the nutritional status of members of the same family]. Ciênc Saúde Coletiva. 2007; 12 (6): 1553-65.

11. Batista Filho M, Rissin A. A transição nutricional no Brasil: tendências regionais e temporais. Cad Saúde Pública. 2003; 19 (Sup.1): S181-S191

12. Correia LL, Silva AC, Campos JS, Andrade FM, Machado MM, Lindsay AC, Leite AJ, Rocha HA, Cunha AJ. Prevalence and determinants of child undernutrition and stunting in semiarid region of Brazil. Rev Saúde Pública. 2014; 48 (1): 19-28.

13. Jehn M, Brewis A. Paradoxical malnutrition in mother-child pairs: untangling the phenomenon of over- and under-nutrition in underdeveloped economies. Econ Hum Biol. 2009; 7 (1): 28-35.

14. Jelliffe DB, Jelliffe EFP. Direct assessment of nutritional status. Anthropometry: major measurements. In: Jelliffe B Jelliffe eds. Community Nutritional Assessment with special reference to less technically developed countries. New York: Oxford University Press; 1989. p. 68-105.

15. WHO Child Growth Standards based on length/height weight and age. Acta Paediatr. 2006; 450 (Suppl.): 76-85

16. Canadian Paediatric Society. Promoting optimal monitoring of child growth in Canada: Using de new World Health Organization growth charts - Executive Summary. Paediatr Child Health. 2010; 15 (2): 77-9.

Received on November 10, 2016

Final version submitted on March 6, 2017

Approved on March 27, 2017
17. Obesity: preventing and managing the global epidemic. Report of a WHO consultation. World Health Organ Tech Rep Ser. 2000; 894: i-xii, 1-253.

18. Amsalu S, Tigabu Z. Risk factors for severe acute malnutrition in children under the age of five: a case-control study. Ethiop J Health Dev. 2008; 22 (1): 21-5.

19. Black RE, Victora CG, Walker SP, Bhutta ZA, Christian P, Onis M, Ezzati M, Grantham-McGregor S, Katz J, Martorell R, Uauy R,Maternal and Child Nutrition Study Group. Maternal and child undernutrition and overweight in low-income and middle-income countries. Lancet. 2013; 382 (9890): 427-51.

20. Keino S, Plasqui G, Ettyang G, van den Borne B. Determinants of stunting and overweight among young children and adolescents in sub-Saharan Africa. Food Nutr Bull. 2014; 35 (2): 167-78.

21. Caulfield LE, de Onis M, Blossner M, Black RE. Undernutrition as an underlying cause of child deaths associated with diarrhea, pneumonia, malaria, and measles [Research Support, Non-U.S. Gov't]. Am J Clin Nutr. 2004; 80 (1): 193-8

22. Sousa B, Almeida M. Alimentação, Nutrição e Crescimento. Rev Aliment Hum. 2006; 12 (3): 93-107.

23. Uauy R, Kain J, Corvalan C. How can the developmental origins of health and disease (DOHaD) hypothesis contribute to improving health in developing countries? Am J Clin Nutr. 2011; 94 (Suppl. 6):1759S-64S.

24. Abrahams Z, McHiza Z, Steyn NP. Diet and mortality rates in Sub-Saharan Africa: stages in the nutrition transition. BMC Public Health. 2011; 11: 801.

25. Kimani-Murage EW, Muthuri SK, Oti SO, Mutua MK, van de Vijver S, Kyobutungi C. Evidence of a Double Burden of Malnutrition in Urban Poor Settings in Nairobi, Kenya. PLoS One. 2015; 10 (6): e0129943.

26. Florêncio TM, Ferreira HS, Franca AP, Cavalcante JC, Sawaya AL. Obesity and undernutrition in a very lowincome population in the city of Maceió, northeastern Brazil. Br J Nutr. 2001; 86: 277-83.

27. Bouzitou G, Fayomi B, Delisle H. Malnutrition infantile et surpoids maternel dans des ménages urbains pauvres au Bénin. Santé (Montrouge). 2005; 15 (4): 263-70.

28. Garrett JL, Ruel MT. Stunted child-overweight mother pairs: prevalence and association with economic development and urbanization. Food Nutr Bull. 2005; 26 (2): 20921. 